\title{
Wyrok Sądu Metropolitalnego w Katowicach (c. Sobański) z 06.12.2005 r. z tytułu błędu co do przymiotu osoby wprost i zasadniczo zamierzonego
}

Ius Matrimoniale 11 (17), 185-190

2006

Artykuł został opracowany do udostępnienia w internecie przez Muzeum Historii Polski w ramach prac podejmowanych na rzecz zapewnienia otwartego, powszechnego i trwałego dostępu do polskiego dorobku naukowego i kulturalnego. Artykuł jest umieszczony w kolekcji cyfrowej bazhum.muzhp.pl, gromadzącej zawartość polskich czasopism humanistycznych i społecznych.

Tekst jest udostępniony do wykorzystania w ramach dozwolonego użytku. 


\section{Wyrok Sądu Metropolitalnego w Katowicach (c. Sobański) z 6.12.2005 z tytułu błędu co do przymiotu osoby wprost i bezpośrednio zamierzonego}

\section{Przebieg sprawy:}

TZ oraz WS zawarli małżeństwo 27.3.1967 w (...). Ważność tego małżeństwa zaskarżyl TZ 29.11.1989 w (...). Sprawę prowadzono z tytulu „udanej zgody stron” oraz z tytułu „błędu co do przymiotu osoby po stronie powoda". Wyrokiem z 28.10.1993 Sąd orzekt, że nie udowodniono nieważności z tytulu „udanej zgody”, udowodniono ją natomiast z tytułu błędu co do przymiotu osoby. Zgodnie z k. 1682 \$1 sprawa znalazła się w Trybunale II instancji. Trybunał ten zdecydował 27.4.1995 rozpatrywać sprawę w drodze zwyczajnego procesu. Dnia 26.2.1999 Trybunał wydał wyrok orzekający z obydwu (a właściwie z trzech) tytulów, mimo że od orzeczenia dokonanego przez Trybunal I instancji odnośnie do symulacji nikt nie apelował. Trybunal zatwierdził wyrok I instancji w części dotyczącej symulacji, uchylił natomiast w części dotyczącej nieważności małżeństwa z tytułu błędu, stwierdzając że również $\mathrm{z}$ tego tytułu nieważność nie została udowodniona. Na prośbę powoda z 20.6.2004 Najwyższy Trybunał Sygnatury Apostolskiej - uzyskawszy wymagane wyjaśnienia - reskryptem z 28.4.2005 (Prot. N. 36549/05 CP) wyznaczył Sąd Metropolitalny w Katowicach do rozpatrzenia sprawy w III instancji. Akta sprawy nadeszły 23.5. i 12.7.2005. Powód nie przedłożył nowych wniosków dowodowych, pozwana nie odpowiedziala na pisma Sądu. Przedmiotem sprawy jest pytanie, czy udowodniono nieważność małżeństwa z tytułu błędu powoda co do przymiotu pozwanej, bezpośrednio i zasadniczo zamierzonego.

\section{Prawny i faktyczny stan sprawy:}

1. Zadaniem Sądu jest rozstrzygnięcie, czy udowodniono nieważność małżeństwa. Gdy powód wnosil 28.11.1989 o orzeczenie nieważ- 
ności małżeństwa, podał jako przyczynę nieważności „brak dzieci z winy żony". Tytuly rozpatrywania sprawy ustalono z powodem przy zawiązaniu sporu, pozwana uznała je za niesłuszne. W obecnym stanie sprawy pozostaje do rozpatrzenia kwestia, czy powód zawierał małżeństwo będąc w błędzie co do przymiotu pozwanej, przy czym przedmiotem tego błędu była zdolność pozwanej do poczęcia i zrodzenia potomstwa.

2. Wpływ błędu co do przymiotu osoby na ważność małżeństwa należy do trudniejszych zagadnień kanonicznych, kanonistycznych i orzeczniczych. Trudność ta znajduje odbicie w ewolucji prawa. Norma k. 1097 \$2 KPK1983 brzmi inaczej niż regulująca tę samą materię norma k. $1083 \S 2$ n. 1 KPK1917. Małżeństwo stron zostało zawarte 27.3.1967, a więc w czasie, gdy obowiązywał KPK1917. Niestety, Trybunały poprzednich instancji nie zwrócily na ten fakt uwagi, nie rozważyły, czy między poprzednim i obecnym prawem zachodzi różnica, a jeśli tak, to którę normę - k. 1083 \$2 n. 1 KPK1917 czy k. $1097 \S 2$ KPK1983 - należy zastosować do rozpatrywanej sprawy. Kwestia ta wymaga uprzedniego rozważenia.

3. Małżeństwo stron zostało zawarte za „rządów” KPK1917. Odnośny przepis prawa opiewał, że błąd co do przymiotu osoby powoduje nieważność małżeństwa tylko wtedy, gdy bląd taki jest równoznaczny z blędem co do osoby (k. $1083 \$ 2$ n. 1), co znaczylo, że chodzilo o przymiot określający, charakteryzujący i indywidualizujący osobę - czyli o przymiot, bez którego dana osoba bylaby ,inną osobą”. Bląd dotyczył tożsamości osoby, a zachodząc powodował - wedle zgodnej opinii autorów - nieważność małżeństwa z prawa natury.

Od roku 1970 (sent. c. Canals z 21.4.1970 - Dec. 52,1970,371) zaznaczyła się w orzecznictwie rotalnym ewolucja rozumienia tożsamości osoby, powodująca postrzeganie jej nie tylko w sensie fizycznym, lecz w sensie bardziej integralnym jako zespół cech psychologicznych, etycznych, kulturowych i społecznych. Znaczyło to, że błąd co do przymiotu zachodzi, kiedy spogląda się na daną osobę fizyczną z określonego punktu widzenia, w jakimś ważnym aspekcie. Błąd co do przymiotu osoby powodował nieważność małżeństwa wtedy, gdy dotyczył przymiotu przesłaniającego osobę (,,ratio personae cedit rationi qualitatis" - sent. c. Heard z 14.1.1956 - Dec. 38,1956,49): przymiot jest zamierzony wprost, a osoba niejako ubocznie. W ten sposób uksztaltowało się orzecznictwo, które stoi u genezy k. 1097 §2 (sent. c. Funghini z 24.4.1988, Dec. 80,1993,142-147). 
Przepis k. $1097 \$ 2$ jest przeto precyzyjniejszym, wyrosłym z doświadczenia procesowego ujęciem dawnego przepisu k. $1083 \S 2$ n. 1 CIC/1917. Nie ulega więc wątpliwości, że rozpatrywanie sprawy można oprzeć na k. 1097 \$2.

4. Kan. 1097 \$2 brzmi: „Bląd co do przymiotu osoby, chociażby był przyczyną zawarcia małżeństwa, nie powoduje nieważności małżeństwa, chyba że przymiot ten byl bezpośrednio i zasadniczo zamierzony”. Przepis powyższy zakłada, że pragnący zawrzeć małżeństwo poznają się zazwyczaj w sposób wystarczający dla podjęcia decyzji matrymonialnej, ale poznanie takie nigdy nie jest pełne czy doskonałe, nie wyklucza błędu. Zaistniały ewent. błąd nie powoduje nieważności małżeństwa, i to nawet wtedy, gdy wywolał decyzję na zawarcie małżeństwa. Co więcej, nie powoduje on nieważności małżeństwa nawet wówczas, gdy dotyczy jedynego przymiotu motywującego decyzję na ma1żeństwo. Słowa kanonu są tu wyraźne. Nie stosuje się przeto k. 1097 §2 do przypadków ujmowanych w stwierdzeniu: ,gdybym był wiedział, nie zawierałbym małżeństwa". I to niezależnie od tego, czy zawierający małżeństwo zastanawiał się nad odnośnym przymiotem (i zawieral małżeństwo w błędnym przekonaniu o jego istnieniu) czy też w ogóle się nie zastanawiał, zakładając bezrefleksyjnie istnienie u partnera przymiotu skłaniającego do zawarcia małżeństwa. Decyzja zawarcia małżeństwa zawsze jest decyzją na niepewną przyszłość i jak każda decyzja życiowa mieści w sobie ryzyko blędu. Możliwość blędu jest wkalkulowana w decyzję matrymonialną, a faktyczny błąd nie może jej zniweczyć. Równocześnie jednak zasada, że przyczyną sprawczą małżeństwa jest akt woli, powoduje, iż prawo nie może ignorować przypadków, kiedy ów akt woli w chwili zawierania małżeństwa trafia w próżnię właśnie dlatego, że brak tego, do czego był skierowany. Stąd dyspozycja k. 1097 \$2.

Błąd co do przymiotu powoduje nieważność małżeństwa wtedy, gdy dotyczy przymiotu bezpośrednio i zasadniczo zamierzonego. Błąd taki dotyczy przymiotu, nie osoby. Nie ma znaczenia, czy przymiot ten motywował zawarcie małżeństwa, ani też, czy i w jakiej mierze przymiot ten stanowi jakość charakteryzującą osobę, istotne jest, że wola ma1żeństwa (niezależnie czym motywowana) jest skierowana bezpośrednio i zasadniczo na ten przymiot. Decydujące znaczenie ma to, że przymiot osoby, który jest cechą akcydentalną, staje się intencjonalnym przedmiotem zezwolenia małżeńskiego, identyfikuje osobę tak, że to, co jest akcydentalne (przymiot), wysuwa się w wizjerze nuptu- 
rienta na pierwszy plan, a osoba schodzi w jego realnej woli na plan drugi: wybiera się partnera ze względu na przymiot, a nie ze względu na ,jego samego". Przymiot taki ,akcydentalizuje” osobę, tzn. wszystkie inne cechy składające się na jej tożsamość. Jeśli przeto zachodzi błąd co do takiego bezpośrednio i zasadniczo zamierzonego, a więc wyznaczającego zezwolenie małżeńskie, przymiotu, wtedy ma miejsce błąd nie akcydentalny, lecz „substancjalny”. Przy aplikacji k. 1097 §2 nie ma znaczenia waga owego przymiotu, istotny jest aspekt subiektywny, tzn. to, czy był on bezpośrednio i zasadniczo zamierzony, i to zamierzony faktycznie, a nie w sposób domniemany. Istotny jest stan woli nupturienta, która faktycznie ma za swój obiekt ów przymiot, niezależnie od tego, czy temu daje wyraz.

W postępowaniu dowodowym trzeba przeto wykazać faktyczne a nie domniemane tylko - skierowanie woli na obiekt (przymiot), co do którego zaszła pomyłka. Istotną rolę odgrywa oświadczenie samej zainteresowanej osoby, przy czym do Sądu należy ocena, czy owo ukierunkowanie woli na określony przymiot zachodzilo faktycznie czy też jest - już w trakcie procesu - retrospektywnie interpolowane czyli przyjmowane hipotetycznie lub po prostu jest subiektywną interpretacją. Dla uzyskania odpowiedzi na te pytania trzeba sięgnąć w czas przed- i poślubny: wyświetlić cechy osobowe nupturienta, przyjętą przezeń hierarchii wartości, doświadczenia życiowe - wszystko to, co mogło wplynąć na ukierunkowanie woli na ów przymiot. Równie ważne są wydarzenia poślubne, wśród nich reakcja w chwili zorientowania się co do błędu.

Dla prawidłowej aplikacji k. 1097 §2 ważne jest odróżnienie normowanego w nim blędu od warunku co do teraźniejszości. Postawienie warunku zakłada istnienie wątpliwości i niepewności, osoba stawiająca warunek chce zweryfikować istnienie jakiegoś przymiotu. W przypadku błędu istnienie zamierzonego przymiotu uważa się za pewne, nie zachodzą wątpliwości: błąd to zdanie (przekonanie) pewne, ale niezgodne z rzeczywistością.

5. W rozpatrywanej sprawie należało przeto udowodnić: 1) że płodność pozwanej była jako jej cecha przymiotem wprost i bezpośrednio przez powoda zamierzonym, 2) faktyczną bezplodność pozwanej oraz 3) błędne przekonanie powoda, że pozwana jest płodna. Bez znaczenia dla sprawy (skoro jest prowadzona z k. 1097 \$2, a nie z k. 1098) pozostaje, czy błąd powoda wynikal z zatajenia dokonanego przez pozwaną lub jej rodzinę. $Z$ wniosków sformulowanych w wyroku Trybunalu I in- 
stancji wynika, iż uznał on za udowodnioną bezpłodność pozwanej oraz błąd powoda. Nie wynika $z$ wyroku, że płodność pozwanej byla przez powoda wprost i bezpośrednio zamierzona wzgl. - wg sensu normy $1083 \$ 2$ n. $1 \mathrm{CIC} / 1917$ - określała ona powodowi osobę pozwanej.

Uznając przeto - zgodnie z Trybunałem I instancji - że niepłodność pozwanej oraz błąd powoda zostały wystarczająco udowodnione, Sąd musi rozważyć (co zupełnie pominięto w wyroku I instancji) kwestię, czy bląd ten dotyczył przymiotu wprost i zasadniczo zamierzonego. Pytanie, na które należy odpowiedzieć, brzmi: czy powód zamierzał zawrzeć małżeństwo z matką przyszłych dzieci, i za taką - błędnie - postrzegał pozwaną, czy też zamierzał zawrzeć małżeństwo z pozwaną, w oczywistym - ale błędnym - przekonaniu o jej płodności. W pierwszym przypadku małżeństwo byloby nieważne, w drugim byłoby ważne.

6. Można zgodzić się ze stwierdzeniem Trybunału I instancji, że powód bardzo chciał mieć dzieci, brak potomstwa przeżywał jako dramat, był gotów adoptować dziecko, a pozwana nie mogła mieć dzieci, zaś adoptować nie chciala. Trudniej zgodzić się z twierdzeniem, że powód poznawszy pozwaną ,identyfikował ją jako przyszłą matkę swoich dzieci" - w aktach sprawy brak przesłanek takiego twierdzenia, można najwyżej twierdzić, że powód nie wątpił, iż pozwana zrodzi mu dzieci. Nie jest to jednak równoznaczne z postrzeganiem plodności żony jako przymiotu wprost i zasadniczo zamierzonego. Powód zeznaje, że zawierał małżeństwo $z$ wielkiej miłości, czyli chodziło mu o pozwaną, po której spodziewal się potomstwa, nie zaś w pierwszym rzędzie o matkę dla upragnionych dzieci. Akta sprawy nie dają żadnych podstaw do twierdzenia, że płodność pozwanej stanowiła dla powoda przymiot wprost i zasadniczo zamierzony. Przesłanek takiego twierdzenia nie ma też w zeznaniach powoda.

7. Sąd docenia starania powoda o uregulowanie jego sprawy małżeńskiej. Nie sposób nie zwrócić uwagi, że sprawa toczy się już 16 lat, z tym większym żalem Sąd orzeka o nieudowodnionej nieważności małzeństwa. Sąd jednak - jak też wszyscy wierni - musi kierować się prawem kościelnym, którego normy - z jednej strony - mają pomóc wiernym w rozwiązywaniu ich trudnych sytuacji życiowych, ale te $\dot{z}-$ po wtóre - musi dokonywać się to zgodnie z zasadami wiary. Do nich należy też prawda o nierozerwalności małżeńskiej. Dla orzeczenia nieważności Sąd winien był - przyporządkowując do stanu faktycznego normy prawa - osiągnąć moralną pewność o nieważności małżeństwa. Tej pewności Sąd niestety nie osiągnąl. 
Sąd podziela argumentację Trybunału II instancji, dokonaną przez Trybunał interpretację k. 1097 \$2 Sąd uznaje za sluszną i poprawnie zastosowana.

Wobec takiego stanu sprawy Sąd odpowiada przecząco na pytanie procesowe i orzeka, że nie udowodniono nieważności małżeństwa. Tym samym Sąd zatwierdza - w rozpatrywanej części - wyrok II instancji. 